\title{
Cow Care and the Ethics of Care
}

My aims in this chapter are, first, to show a way of approaching animal ethics broadly speaking through the lens of Hindu thought, while keeping the focus on cow care as a value to be pursued and realized. Here the question can be phrased, how can Hindu thought contribute to a general discourse on animal ethics? The second aim is to bring non-Indian (Western) animal ethics thought to bear on Hindu animal ethics (including the pursuit of cow care). What elements of Western animal ethics discourse can complement and make more comprehensive, persuasive, and comprehensible, the traditional Hindu (or Indic) discourse, leading toward a more inclusive and comprehensive vision of nonhuman animal care while also giving appropriate place for cow care in particular?

Our discussion will revolve largely around three key terms found in Hindu traditions, two of which we already encountered in Chapter 2, namely dharma and bhakti. A third term, yoga (briefly alluded to in that chapter), will also be important. These terms, each with their respective (and overlapping) semantic fields, are central to early brahmanical Hindu texts (also already introduced in Chapter 2) including the Mahabharata 
(with its important dialogue on ethics, the Bhagavad Gita) and the Bhagavata Purana. An additional relevant classical text to be introduced here is Patanjali's Yoga Sutras (YS), a highly influential work on the philosophy and practice of yoga. Yoga, an important current in Hindu thought and practice since ancient times, may be seen as a conceptual and practical link in the "polarity of value" identified in Chapter 2, serving to integrate dharma and bhakti into a comprehensive worldview from which ethical thought and action unfold. Because each of the terms - dharma, yoga, and bhakti-carry significance characteristic of conceptual "patterns," we will have occasion to refer to each as paradigms - the dharma paradigm, the yoga paradigm, and the bhakti paradigm (Long 2013).

From the Western perspective, we will give attention mainly to the recently developed ethics of care discourse, particularly as applied to animals. We will also consider animal rights discourse, particularly as reconceived in terms of (domestic) animals-as-citizens, a notion that will lead us into a brief discussion concerning the politics of cow care, especially in light of anticipatory communities (Rasmussen 2013) as locations of a dharma-based communitarian political theory to support animal care. In the course of this discussion, I consider abolitionist objections to animal citizenship in relation to Hindu cow care to argue, in part, that while a reduction of dairy consumption by humans may be appropriately called for, rather than complete elimination of dairy consumption (and thereby the ultimate abolition of bovine domestication), a positive dharmic, yogic, and bhakti ethic of cow care best serves the higher ideal of freedom and felicity for all beings. Ultimately what is aimed for is a sense of devotional service (seva), as both means and goal of realizing the good.

\section{Dharma and Animal Ethics}

Dharma is a major sphere of Hindu thought and practice that necessarily contributes to any discussion of animal ethics. This may be obvious, since it is generally regarded as that sphere of Hindu thought particularly concerned with duty, law, and the sustaining of social and cosmic order. Along with the normative dimension of dharma is its equally important descriptive aspect. As description, dharma can mean nature, character, 
peculiar condition, essential quality, or property. We might call it the is aspect of the is versus ought distinction in ethical discourse. Dharma as normativity corresponds to the ought dimension, whereby the term approximates notions of "good works, practice, customary observance or prescribed conduct" (Monier-Williams [1899] 1995, pp. 510-511). These two dimensions combined point to dharma as the sphere of human culture that aims to bridge (or close) the gap between is and ought. ${ }^{1}$ In other words, dharma aims to effectively address the reality of an ever-contingent world of fault, danger, and disorder (all implied in the term adharma, the lack of or opposition to dharma $)^{2}$ with the appropriate vision and means to realize what ought to be (the good).

Considering animal ethics in terms of dharma, we must note two different yet overlapping aspects of dharma's normativity. The first aspect comprehends act-centered, moral obligational, deontic (dutybased) ethics, in terms of both deontology and consequentialism (Fink 2013, pp. 669-670), in what we may refer to respectively as dharma as settled duty and dharma as deliberation on duty. Dharma as settled duty is typically based on what are considered clear and fixed identities, such as one's varna (brahmin, kshatriya, and so on). ${ }^{3}$ Dharma as deliberation is

\footnotetext{
${ }^{1}$ Thus, a modern Western parallel can be found in Immanuel Kant, with his project to "maintain a balance between the actual and the possible" (see Neiman 2008, p. 137). Frazier (2017, p. 154), discussing structuring practices in Hindu traditions and referring to anthropologist Clifford Geertz, notes: "Like Geertz's model of a worldview, the various structuring practices of Hinduism thus have two dimensions in that they are both descriptive, highlighting the potential for order in the world, and also prescriptive, encouraging human beings to help create and sustain that order."

Sanskrit texts concerned with dharma also emphasize that it is humans who practice, or observe, or uphold dharma, whereas nonhuman animals - though doubtless pursuing their purposes in wonderful ways (Nussbaum 2011, pp. 239-240) — cannot be said to pursue dharma in its normative sense. A well-known Sanskrit proverb in the Hitopadeśa of Narayana states (0.30), "Eating, sleeping, feeling afraid and copulating-these things men have in common with animals. But man distinguishes himself by doing his duties [dharma]; those who neglect them are like beasts" (Törzsök 2007, p. 67). This distinction in no way gives license for humans to exploit animals, and neither does it forbid humans to engage with animals in non-exploitative ways.

${ }^{2}$ See Glucklich (1994, pp. 7-10) and passim for a phenomenological study of dharma and adharma. Here, I focus mainly on textual expressions of these terms.

${ }^{3}$ The modern term "caste" refers generally to what in India is called jati-one's clan-related identity associated more or less with occupation and assumed to be determined by birth. Some 3000 jatis have been identified in modern India. Varna, on the other hand, is a broad, fourfold categorization that, according to the Bhagavad-gita, is not based on birth; rather, it is determined by guna (quality) and karma (activity) (Bg. 4.13). The four varnas are the brahmins (brahmanas — priests, teachers);
} 
foregrounded when, for example, identities or circumstances are ambiguous or in situations of moral dilemmas. The second aspect comprehends virtue ethics and may be called dharma as virtue - the sphere of ethical reflection and practice that locates the basis of right action in the cultivation and exercise of one or more virtues, qualities, or dispositions. ${ }^{4}$

\section{Dharma as Settled Duty}

Dharma as settled duty recognizes that humans live amid what Jessica Frazier calls "layers of embodiment," a condition involving complex relations of an individual human being not only with other humans, but also with other beings, both visible and invisible. At the heart of these relations is the fact of dependency and interdependency, which points, first and foremost, to obligations. But the dharmic sensibility also recognizes that we humans have agency, choice, and indeed creative power by which we seek to access hidden possibilities and bring them under our control (Frazier 2017, pp. 195-198).

Frazier's suggestive phrase "hidden possibilities" calls our attention to a further basic feature of dharmic sensibility, namely, that the real is inclusive of dimensions that are (generally) beyond human perceptions of time and space. ${ }^{5}$ As we noted in Chapter 2, in Hindu traditions the universe is understood to be populated with powerful beings—-gods (devas) or divinities and lesser beings that have agency and influence in the world, and to whom humans, as beneficiaries of godly power and order, are

kshatriyas (ksatriyas — administrators, rulers); vaishyas (vaisyas —farmers, bankers, business people); and shudras (śüdras-laborers, artisans).

${ }^{4}$ We may take Alexander's and Moore's (2016) brief definition of deontological ethics as a good reference point in relation to consequentialism and virtue ethics: "[D]eontology falls within the domain of moral theories that guide and assess our choices of what we ought to do (deontic theories), in contrast to those that guide and assess what kind of person we are and should be (aretaic [virtue] theories). And within the domain of moral theories that assess our choices, deontologists- those who subscribe to deontological theories of morality-stand in opposition to consequentialists."

${ }^{5}$ If we think of normative dharma as a legal discourse, it clearly displays a theological dimension. Speaking of law in general, Donald Davis notes how law is the product of theological reflection about the mundane world. "The act of reflection converts a mere act, a movement of the body, into an obligation. This kind of reflection, focused as it is on the ordinary world and ordinary actions, is theological because it is a reflective attempt to impart meaning and purpose to quotidian acts" (Davis 2010, p. 3). 
expected to offer due respect. Humans thereby also are understood to fulfill their specific role in the maintenance of cosmic order.

Classical brahmanical Hindu tradition expresses this sensibility of obligation particularly in the practice of the fivefold sacrifice (pancha-yajna). This is a daily practice enjoined for brahmin householders to acknowledge and repay debts that are congenital or existential (not contractual but nonetheless existing).

[A] person is indebted to the deva-s, the managers of the forces of nature, for supplying the means to sustain his or her body (deva-rinam); to the seers of yore, the rishi-s, and the teachers who received and then passed on the knowledge about the ultimate meaning of life and the means to attain it ... (rishi-rinam); to the pitri-s, or former generations who helped him or her to be what and where s/he is now (pitri-rinam); to the goodwill and support of his and her fellow humans (nri-rinam) and to all living beings who help that person to sustain him- or herself (bhu-rinam). (Stamm 2015, p. 94)

The Dharmashastra texts prescribe methods for addressing each of the five debts, involving, for example, daily ritual oblations for the devas, of uncooked grains and clarified butter into the home's perpetually burning sacred fire. Hospitality is strongly enjoined for the householder; hence, the debt to humanity is absolved especially through hosting strangers in the home and by providing the needy with food, clothing, and land. The debt to nonhuman living beings is addressed by making feed available to both domesticated and non-domesticated creatures. ${ }^{6}$

To be sure, this fivefold sacrifice of orthodox brahmins reflects and affirms the conservative worldview that these persons embody. In this worldview, human life is to be well but austerely lived so that the good is accomplished in widening spheres of rule-bound life. Personal and direct family good is accomplished as the rule-bound tradition is preserved and

${ }^{6}$ The Manusmriti (3.70) refers to the fivefold sacrifices as maha-yajnas, or "great sacrifices," indicating their centrality in the ritual life of the brahmin householder. Davis suggests a connection between this system and the triple debt enjoined in the relatively early (c.800-600 BC) Taittiriya Samhita: "A Brahmin, at his very birth, is born with a triple debt-of studentship to the seers, of sacrifice to the gods, of offspring to the fathers. He is, indeed, free from debt who has a son, is a sacrificer, and who has lived as a student" (Davis 2010, pp. 71-72). 
perpetuated, with the reward of eventual rebirth into the same tradition and possibly into the same family. These same rules uphold the sense of continuity that is valued as a social good, and the sense of cooperation and participation sustained by prescribed actions yields a confirmation of cosmic good.

Yet embedded in this world of rules is also an important lesson for the householder: He must not become subject to possessiveness. Rather, he (and the texts do privilege the male householder) is to be generous, functioning within a cosmic system of exchange that is conducive to fostering a sense of honoring all beings appropriately according to position and needs. ${ }^{7}$ As Donald Davis notes, in this worldview, the notion of debt functions as a metaphor for law in general, as a "vision [suggesting] an ethics of the controlled self-emptying of one's personal character and substance into the world as a way of pursuing religious salvation" (Davis 2010 , p. 71). By such "controlled self-emptying," the brahmin aims at going beyond the boundaries of worldly existence to become a knower of brahman, the unbounded ultimate reality of being.

\section{Dharma as Deliberation on Right Action}

Dharma can also be construed as the practice of ethical deliberation, making choices for right action responsive to ever-changing contingencies, based on the resources of dharma tradition, injunctive dharma texts, and sagely guidance. Such deliberation may involve careful interpretation of dharma texts, a practice that developed into a veritable philosophical school from early centuries of the Common Era, the Mimamsa (literally, "deliberation") school. A noteworthy example of the Mimamsa way

\footnotetext{
${ }^{7}$ See Frazier (2017, pp. 141-147) for a summary of modern scholarly interpretations of Hindu brahmanical ritual, which she broadly classifies as functionalist theories of social constraint versus emphasis on elements of creativity and self-determination that shows "a participatory, innovative and expressive dimension in many practices" (p. 145). She further summarizes her summary: "These various theories of ritual action thus reflect the open, malleable character of the Hindu cosmos: embodiment is naturally active, but this means that it is volatile, dynamic and must be constrainednevertheless it can be controlled in order to reshape (both outer and inner) reality and gain the highest levels of the universe for the practitioner. The self...embodied in the physical and mental materials of the universe can be controlled through special practices, but it can also be trained to use its powers creatively, in order to become or interact with higher levels of the cosmos" (pp. 146-147).
} 
of reasoning is one particular analysis of a dharma text passage we already considered in Chapter 3, namely the Manusmriti's seemingly contradictory injunctions on eating or abstaining from animal flesh. In his discussion of this oddly incongruous passage, the tenth-century Mimamsa commentator Medhatithi argues for its consistency. To do so, he draws on a common Mimamsa interpretive technique, namely the distinction between a rule and an explanation or exhortation, concluding that it is (as a rule) indeed legally permissible to eat certain types of meat, and there is (as an exhortation) a "legal and moral enticement to abstain from it." For Medhatithi, Donald Davis explains,

$[\mathrm{K}]$ illing and eating meat in specified contexts is legally permissible, but the law does not stop there. Instead, a fully hermeneutic understanding of law demonstrates that the law calls on us to abstain from the actions for the "great rewards" that abstention brings. Both are the law, dharma, but the dharma that produces higher reward is to be preferred over that of mere acceptability. (Davis 2010, pp. 57-58 and n. 19)

Important to note from this example is the acknowledgment of choice: While the act of meat-eating is understood to be permitted, human beings can-and do well to- choose not to do so. Further, although the nonmeat option involves an enticement of "great rewards," there is an implied invitation to awaken awareness that higher rewards must indicate a superior moral position, rooted in a superior understanding of the value of life.

As we saw in Chapter 2, dharma as deliberation is also dealt with extensively in narrative fashion in the Sanskrit textual tradition, famously in the Mahabharata, in which problems portrayed as moral dilemmas highlight the difficulty of deliberating to a satisfactory decision how to act. ${ }^{8}$ And as we saw, in the case of the king who is forced to suffer despite having no ill

\footnotetext{
${ }^{8} \mathrm{~A}$ well-known case in point in the Mahabharata is the attempted disrobing and humiliation of Draupadi, the five Pandavas' wife in common, in the dice match assembly. Yudhishthira, the paragon of dharma, in a gambling stupor, loses all his possessions and brothers and then himself, and even their wife, to the Kauravas. Draupadi's sharp-witted challenge to these proceedings is met with silence by the seniors present. It is in the silences, notes Vrinda Dalmiya, that can be heard the message of questioning dharma's adequacy to resolve ethical quandaries and thereby the "crying needs of a vulnerable subject" (Dalmiya 2016, pp. 50-52).
} 
intentions in donating a cow that he was unaware was not his to donate, the Mahabharata also raises the question whether it is at all possible to perfectly uphold dharma, even with the best of intentions.

The issue of dharma's place in guiding human right living is related, in the Mahabharata, with a debate on the position of dharma as one of four broad spheres of human aspiration (purusha arthas, mentioned in Chapter 4). Which one of the four spheres is foundational to the others, namely kama - the pursuit of bodily sense satisfaction; artha - the pursuit of wealth, possessions, and self-centered well-being; and moksha-the pursuit of freedom from all forms of bondage, ultimately from the cycle of death and rebirth? Depending on which one of these four is accepted as foundational to the others, radically different ethical approaches unfold. Arguably, the Mahabharata favors the conclusion that dharma holds the foundational position in relation to the other three human aims, which is to say that it considers dharma as an intrinsic value, essential for the realization of any other aims. ${ }^{9}$ But when dharma is pursued only instrumentally for worldly pleasure and gain, to realize kama and artha, rather than as an end in itself and to the neglect of moksha (including the affirmation and protection of others' freedom and dignity), dharma's purpose and power as a process of ethical deliberation become obscured. ${ }^{10}$ Recognizing this danger, the Mahabharata famously asserts that the true path of dharma, while involving deliberation, also calls for guidance from "great persons" (mahajana). ${ }^{11}$ With such enlightened guidance, dharma can be appropriately re-visioned and applied in response to changing circumstances (Dalmiya 2016, p. 49).

\footnotetext{
${ }^{9}$ Vyasa, the traditional compiler of the Mahabharata, has himself quoted in its final stanzas, saying "I am without pleasure and have raised my arms, but no one is listening to me. If dharma and kama result from artha, why should one not pursue artha? For the sake of kama, fear or avarice, and even for the sake of preserving one's life, one should not give up dharma. Dharma is eternal. Happiness and unhappiness are transient. The atman is eternal, but other reasons are transient" (Debroy 2015, vol. 10, p. 682).

${ }^{10}$ There is a sense in which all four purusha arthas complement each other, such that a conscientious Hindu seeks a balance among them. Such balance relates to cow care, whereby appropriate and effective care is sustained when it is understood how all four human aims are enhanced by properly caring for cows (Interview with Shrivatsa Goswami, 15 February 2018).

${ }^{11}$ Although widely quoted, the Mahabharata Critical Edition (Sukthankar 1942, vol. 4, p. 1089) places this stanza in an appendix, not recognizing it as part of the text proper.
} 
A fitting example of re-visioned dharma comes in a narrative near the end of the Mahabharata. As King Yudhisthira (son of Yama, considered personified Dharma) prepares for death during his Himalaya ascent accompanied by a dog, Indra, chief of the celestials, invites the king to take his place in heaven. Yudhisthira is pleased to oblige, but not without his faithful and dependent dog. Indra's insistence that no dogs can reside in heaven confronts Yudhisthira's firm resolve not to leave his canine companion behind. The impasse dissolves when the dog reveals himself to be the celestial personification of Dharma. ${ }^{12}$ As Vrinda Dalmiya notes, this story shows Yudhisthira "finding his relational self" (Dalmiya 2016, p. 63), suggesting that dharma's deeper purpose, beyond regulative normativity, is self-transformation. This idea leads to the second major conceptualization of dharma, namely as cultivation of virtue or as virtue-nourishing practice.

\section{Dharma as Cultivation of Virtue}

The identification of dharma with deontological and consequentialist ethics would not, by itself, give a full sense of dharma's substance and meaning in Hindu tradition. What Western traditions call "virtue ethics" plays a major role in Hindu tradition in the form of extensive praise for a wide variety of virtues and praise for persons who show these virtues. Further, we can find substantial exhortation for individuals to consciously cultivate within themselves either specific virtues or a virtuous disposition. Particularly in this context, dharma is characterized by its didactic function, instilling a sense of humility, obligation, and responsiveness to contingencies of worldly conditions. Learning to nurture such virtues is

\footnotetext{
${ }^{12}$ From the ethics of care perspective (which we will discuss shortly), Dalmiya (2016, p. 63) suggests that this episode highlights how Yudhisthira "finds his relational self," a self that is fundamentally related with, and therefore impelled to respond to, the needs of other beings. In discussing another Mahabharata story of animals - in this case a dove and a hawk - involving a king's resolve to protect the vulnerable dove, Veena Howard (2018, p. 130) writes, "The animal parables [in the MBh] using the tropes of disguised gods invite us to listen to animal voices for understanding the deeper messages embedded in the tales, messages that disrupt speciesism and address ethical concern for animals themselves."
} 
understood to render a favorable mentality for conducting right action according to context.

From Chapter 2, we recall the Bhagavata Purana's allegory of the bull, Dharma personified: Three legs — compassion, austerity, and purity-have been wounded or destroyed by Kali-the embodiment of time's cycle of degradation - and the remaining leg-truth-barely functions. As a bull stands and moves on four legs, the bull that is dharma-righteous action engendering and sustaining well-being that can lead to liberationis supported by four "legs," each of which can be regarded as a virtuenurturing practice. Each practice supports and enhances the other three, and together, if conscientiously pursued, they support a life characterized by "illumination" (sattva). ${ }^{13}$ Specifically, compassion fosters right action toward the weak and vulnerable; austerity fosters self-restraint in relation to one's own desires; purity fosters respect for sexual boundaries; and truth can be construed, in this context, as the practice that fosters higher selfawareness in comprehending the reality of personhood constituting all beings and right action arising from such awareness in relation to the environment.

In the debilitation or absence of the first three (compassion, austerity, and purity), the power to discern objective truth becomes crippled and truthfulness is compromised, degenerating into cultures of half-truth and untruth, devolving yet further into individual and collective illusion and delusion. Hence, the Bhagavata Purana claims that in the present age, the purpose of dharma - realizing the good-becomes severely compromised, and dharma is largely neglected as a viable means for establishing appropriate ethical guidance of human relations with nonhuman animals. ${ }^{14}$ In this condition, humans tend to neglect illuminating (sattva) values and become driven by passion (rajas) and covered by darkness (tamas). These latter two qualities of living (gunas) severely limit the ability to uphold

\footnotetext{
${ }^{13}$ Here, a distinction should be made between this sense of virtue as an intrinsic moral value and virtue as "pious credit" (punya), a sort of positive karmic capital that is a reward for pious action. Rather, by virtue-nurturing practice I point to the cultivation and habituation to a disposition characterized in the Bhagavad-gita as sattvika or the mode of goodness and illumination.

${ }^{14}$ The Bhagavata Purana (12.2) paints a dark picture of the present age (Kali-yuga), in the future tense. Among several signs of degradation listed are these: "Dharma is observed only for the sake of reputation"; people's occupations are characterized by "theft, lying, and needless violence"; and (oddly), "cows will be like goats" (12.2.6, 13-14).
} 
dignity, freedom, and harmonious attunement of human aspirations with the natural environment and its creatures.

A further reason Hindu dharma suffers neglect and even scorn in the current age is the perception that it is deeply rooted in a hierarchical social paradigm that indulges privileged strata and oppresses the marginalized. Especially dharma texts concerned with rules and law, such as the Dharmashastras, are indeed typically concerned with ranked identities, especially social ranking in the "system" of fourfold occupational divisions (varna). Less known is that such texts are also concerned with dharma principles that apply to everyone, in what is known as "general" dharma (sadharana-dharma). The recognition of commonality indicated by sadharana-dharma - general duties to be followed by all human beings - points to a deeper understanding, whereby differences in qualifications are acknowledged only to empower all persons to realize ontic equality (Sutton 2000, pp. 303-304). ${ }^{15}$ In turn, this deeper aim of dharma points to another key term for Hindu animal ethics, namely yoga-an important paradigm of thought and practice wherein recognizing the ontic equality of all living beings is a vital principle.

\section{From Dharma to Yoga}

Classical yoga serves importantly to further illuminate Hindu animal ethics. In Chapter 2, we suggested that the literature of India of which the Hindu "bovine imaginaire" is derived can be conceptualized in terms of polarities, one of which we called a "values polarity" that stretches between the notions of dharma (as maintenance of cosmic order) and bhakti (as devotion toward an ideal being). Now I want to suggest that this conception will also serve our attempt to understand Hindu animal ethics. Further, I suggest that we can regard the classical yoga tradition as the link that ties dharma and bhakti together, especially as articulated in the Yoga Sutras of Patanjali and as expressed with a strong bhakti inflection

\footnotetext{
${ }^{15}$ Sadharana-dharma can be understood as directives intended for all human beings at all times and which, much more than injunctions for specific groups (sva-dharma), can be identified as injunctions toward the pursuit of morality and the cultivation of virtue.
} 
in the Bhagavad Gita. Somewhat in contrast to the dharma paradigm, yoga is typically represented as a "path" (marga) of systematic, purposeful practice that enables individuals to realize ultimate freedom (moksha) as life's highest aim. Whereas dharma looks in two directions-outward to worldly well-being (kama, pursuit of pleasure, and artha, pursuit of wealth) and inward to ultimate freedom-yoga seeks to bring one fully beyond the impediments of worldly attachments, which invariably draw one into relationships of domination and exploitation, characterized by tendencies toward violation of and violence against other beings. On the other side, in contrast to bhakti's strong emphasis on realizing a divine ideal, a supreme person, as the perfection to be pursued, yoga's emphasis is on rigorous practices to free the mind from all false and illusory conceptions and "afflictions" (klesha), to reach perfect concentration (samadhi) and freedom (kaivalya). ${ }^{16}$

Despite important differences between dharma and yoga paradigms, there are also striking overlaps in some elements of practice, especially elements impacting ethics. In particular, similar to dharma as cultivation of virtue, yoga also demands careful attention to specific practices conducive to fostering virtue. Patanjali's Yoga Sutras, the celebrated summary of classical yoga, includes a description of yoga as an eightfold process (ashtanga-yoga). The first two processes-restraints (yama) and observances (niyama) — each stipulate five components as prerequisites for further progress. ${ }^{17}$ The first of the five yama practices-ahimsa, nonviolence-is already familiar to us from Chapter 3. Yet we do well to linger on this practice in the context of yoga for the particular treatment it receives by classical commentators on Patanjali's Yoga Sutras.

After listing the eight yoga "limbs" (YS 2.29), Patanjali lists five components of restraint, beginning with ahimsa, which the traditional commentator to the text, Vyasa, identifies as the "root" of the remaining four

\footnotetext{
${ }^{16}$ Both moksha and kaivalya have similar meanings, with shades of difference. Patanjali's Yoga Sutras uses kaivalya, whereas moksha is found in texts such as the Mahabharata.

${ }^{17}$ The five yoga restraints (yama) are listed by Patanjali as "nonviolence, truthfulness, refrainment from stealing, celibacy, and renunciation of [unnecessary] possessions" (Bryant 2009, p. 243; YS 2.30).
} 
restraints (Bryant 2009, p. 243). ${ }^{18}$ The next aphorism (YS 2.31) makes clear that the "great vow" to observe the five restraints is meant for everyone, without exception, regardless of social position, place, or time (much like the notion of "general dharma" mentioned previously). As Bryant points out, Patanjali is "being as emphatic here as the straightforward and plain use of human language allows” (Bryant 2009, p. 249).

After listing the five observances (niyama: cleanliness, contentment, austerity, study [of scripture], and devotion to God, YS 2.32), Patanjali offers simple but powerful advice on how to progress in adhering to the restraints and observances: "Upon being harassed by negative thoughts, one should cultivate counteracting thoughts" (YS 2.33). What constitute negative thoughts? The next aphorism explains:

Negative thoughts are violence ( himsa), etc. They may be [personally] performed, performed on one's behalf by another, or authorized by oneself; they may be triggered by greed, anger, or delusion; and they may be slight, moderate, or extreme in intensity. One should cultivate counteracting thoughts, namely, that the end results [of negative thoughts] are ongoing suffering and ignorance. (Bryant 2009, p. 257; YS 2.34)

Since the specific example given of negative thought is violence, traditional commentators give special attention to it. As Bryant notes, the eleventhcentury commentator Bhoja Raja highlights Patanjali's explicit reference to performance of an act (of violence, such as killing an animal) "on one's behalf by another" as a warning to the "dull wit" consumer of meat who thinks he or she can avoid karmic responsibilities by having others do the slaughtering. The fifteenth-century commentator Vijnanabhikshu goes further, saying that even scripturally condoned violence (as in the killing of animals in ritual sacrifices, as we saw in Manusmriti) is herewith rejected (Bryant 2009, p. 258). We should also note Vijnanabhikshu's explicitly theistic reasoning. Bryant summarizes:

\footnotetext{
${ }^{18}$ The restraints are called by Shyam Ranganathan the "five political ideals" in Yoga (2017b, p. 189). Strikingly, he proposes, "Putting non-harmfulness first is to privilege objectivity over truth: when we do not harm, we allow for the objectivity of things in our environment, including ourselves and other people, as self-determining objects in the world. The truths of the world change, from one of tyranny to social freedom. We are hence free to endorse the following ideals of respecting people's property, their sexual boundaries, and not being encumbered by stuff" (p. 190).
} 
Ultimately, all creatures are parts of Iśvara, God, explains Vijñānabhikṣu, like sons to the father and sparks to the fire. Therefore, violence against others is violence against God. He quotes the [Bhagavad-] Gìtā: "Envious people act hatefully towards me [Krishna] in their own and in others' bodies. I continually hurl such cruel hateful people, the lowest of mankind, into samsāric [repeated death and rebirth] existence, into only the impure wombs of demons" (XVI.19). (Bryant 2009, pp. 259-260)

As we noted, nonviolence is regarded as the "root" of all the restraints and observances, all of which together build the ethical foundation for successful yoga practice. And it is noteworthy that Vijnanabhikshu makes an explicit connection between nonviolence and theism, particularly when we consider the last of Patanjali's five observances, namely ishvara-pranidhana-devotion to God. For, according to Patanjali, successful practice of yoga culminates in samadhi-singular absorption of one's awareness in the reality of one's non-physical identity. And, says Patanjali, the specific practice that, when perfected, brings about samadhi is ishvara-pranidhana: "From submission to God comes the perfection of samädhi" (Bryant 2009, p. 279; YS 2.45). This idea confirms the link of classical yoga to bhakti, and we might view it as the Bhagavad Gita's point of departure. There Krishna assures Arjuna (Bg. 6.46-47), "A yogi surpasses ascetics, and is even held to surpass the learned. A yogi surpasses ritualists. Therefore be a yogi, Arjuna. And of all yogiss, I consider as most linked in yoga one whose inner self has gone to Me, who faithfully reveres Me" (Goswami 2015, p. 175).

Through the disciplines of yoga, one may well become largely free from the tendency to commit violence on other beings, and this goes hand in hand with progressive comprehension of ontic equality among all living creatures. Yet yoga's importance for animal ethics is not limited to negative virtue - the avoidance of harming other beings. Just as important is the freedom of action that yoga affords practitioners, including freedom from habitual response to predictable circumstances, thus addressing the problem of dharma as deliberation in the face of unexpected situations (Perrett 1998, pp. 22-23). This freedom, referred to in the Yoga Sutras as kaivalya, is sometimes translated as "aloneness," which Ian Whicher construes as "purușa's [purusha, the living being's] innate capacity for pure, 
unbroken, nonattached seeing/perceiving, observing or 'knowing' of the content of the mind (citta)" (Whicher 1998, p. 276). Such freedom is, very significantly, also enjoyed by the objective world that the yogi perceives. Whicher (p. 278) notes that, although purusha is, from the enlightened perspective, in fact ever free,

it would not be inappropriate to suggest that, figuratively speaking, in the state of "aloneness" (kaivalya) purusa [spirit] and prakrti [the phenomenal world] are simultaneously liberated in that, all ignorance having been removed, they are both "known," included, and are therefore free to be what they are. (emphasis in original)

This has the intriguing implication that it is by virtue of yogic freedom achieved by the yogi that true freedom of other beings can be conceived. In other words, it is within the auspices of yogic perception in the state of freedom that the freedom of beings in general can be properly conceived. Further, because the perfected yogi does not (as is usually interpreted) lose his or her personhood, it is such a person who can properly be considered fit to relate with all creatures in appropriate ways, which means acknowledging their personhood. ${ }^{19}$

Thus far I have suggested that dharma, in the broad sense of injunctive statements and deliberative practices, may be correlated with normative ethics in its two directions-deontic and consequential grounding of action. In its second feature, dharma as cultivation of virtue, dharma shows points of commonality with the two initial components of yoga, the practice of five restraints and five observances. In all these cases, points of relevance to animal ethics lean strongly on the side of prohibition or negative ethics. The sense of responsibility that humans may have toward nonhuman animals, as might be derived from these texts and their interpretive traditions, is largely one of providing minimally for certain animals and otherwise refraining from intentionally harming them. In more positive terms, the dharma and yoga paradigms of thought and action unsettle

${ }^{19}$ Whicher $(1998$, p. 277$)$ writes, "[I]t can be stated that kaivalya in no way presupposes the destruction or negation of the personality of the yogin, but is an unconditional state in which all the obstacles or distractions preventing an immanent and purified relationship or engagement of person with nature and spirit (purusa) have been removed." For a detailed discussion on the meaning of kaivalya in YS, see Whicher (1998, pp. 275-294). 
anthropocentric presuppositions, locating the value of human existence in the facility it gives for realizing an ultimate cosmic order (through dharma) and for realizing atemporal selfhood, free from self-serving action (through yoga).

A third dimension to this picture of Hindu animal ethics is to be found in the bhakti current, or paradigm, which we have touched on briefly in previous chapters. Now we revisit this theme as we consider how it may contribute to a positive vision and practice of animal ethics, especially as articulated in a relatively recent development in Western ethics discourse, the ethics of care.

\section{From Yoga to Bhakti}

Turning toward the bhakti end of the dharma-bhakti polarity of value, we keep in mind the linking function of yoga between dharma and bhakti. The term "bhakti" - typically translated as "devotion"- -is often linked to the term "yoga" in the bhakti literature (Bryant 2017). ${ }^{20}$ Thus, bhakti-yoga is the regular and intentional practice of devotion, pursued with an aim to realize the self as essentially relational. Whereas classical yoga regards desire (raga) as an obstacle to be overcome for making progress, in the domain of bhakti, the aim is to channel one's desires and love toward the supreme person, as the ultimate object of relationship and love (Bryant 2017, p. 66). To do so constitutes the perfection of practice, leading to further devotional activity rather than to any sort of cessation. In terms of moral theory, as Shyam Ranganathan explains, bhakti can be seen as a fourth, distinctly Indian, theory apart from the three commonly accepted categories, namely virtue, deontic, and consequentialist theories. Distinctive of bhakti as a moral theory is that engagement in bhakti practice ("doing the right") is itself "the good" outcome, whereas with the other three theories, there is a necessary distinction between the right and the good (Ranganathan 2017a, pp. 26-27). ${ }^{21}$

\footnotetext{
${ }^{20}$ For a summary of Chaitanya Vaishnava texts (especially Bhagavata Purana) linking yoga and bhakti, see Sinha (1983, pp. 39-43).

${ }^{21}$ The distinctiveness of bhakti as the culmination of Hindu thought has been carefully articulated by Jarava Lal Mehta (1912-1988). Ellis (2013, pp. 126-128) elaborates on Mehta's analysis of the
} 
To channel one's desires and love toward the supreme person is to simultaneously cultivate a deep sense of relationality with all creatures. An extended episode in the Bhagavata Purana (5.8-13) illustrates how yoga imbued with bhakti becomes the basis for deep relationality between human and nonhuman animals, and how this sensibility can have the power to transform the heart of one initially blind to the value of such relationality. In this episode, an ascetic sage, Bharata, formerly a king who renounced his kingdom to seek yogic perfection, is intently practicing yogic meditation alone in a forest. One day, he becomes suddenly distracted by the roaring sound of a lion. Seeing that a pregnant deer, in her fear of the lion, has given birth to a fawn before expiring, Bharata takes the orphaned fawn to his hermitage. There he raises the fawn with tender care, but in doing so he becomes increasingly drawn away from his yoga meditation practice. Indeed, his care for the fawn becomes so absorbing that, as he meets with an accident and loses his life, because his thoughts at the moment of death were on the young deer, Bharata's immediate next birth is as a deer. Remembering his previous life of yoga practice, deer Bharata finds shelter in the hermitage of other sages until his life in this form comes to a natural end. ${ }^{22}$ The Bhagavata Purana continues the story, with Bharata's subsequent birth occurring in a brahmin family where, because now his determination to reach yogic perfection has become so intense, in order to avoid the distractions of brahmin social life, from earliest childhood he feigns as a deafmute (jada). This serves his purpose of keeping his attention fully on the practice of bhakti-yoga, although he thereby suffers considerable abuses from relatives.

Having grown to adulthood, because he is well built, Jada Bharata, as he is now known, is conscripted into service as a palanquin bearer for

\footnotetext{
"logic of the Hindu tradition" as having a trajectory with three hermeneutical focal points, namely the Rigveda, including the Upanishads; the epic tradition, especially the Mahabharata; and finally, the Bhagavata Purana. It is the latter text that brings forth the tradition's culmination in virahabhakti, love-in-separation, the most intense mode of love for the other. It is this mode of love that is seen as the good that is realized, even if incompletely in early stages of practice, by the right practice of bhakti.

${ }^{22}$ The text does not explicitly indicate it, but the implication is that Bharata, in the deer body, would have benefitted from hearing the discussions on spiritual culture conducted by the sages. A similar notion is found in Buddhist literature and among present-day Buddhist monks of Sri Lanka, both of which indicate a belief that "passively listening to dharma preaching, whether it is understood or not, has spiritually productive consequences" for animals (Stewart 2017).
} 
the provincial ruler, Rahugana. But Jada Bharata fails to keep pace with the other bearers, being preoccupied in avoiding harm to ants as he steps forward. The resulting shaking of the palanquin precipitates the king's anger and abusive words. Jada Bharata now breaks his lifelong silence. In the course of the ensuing dialogue between him and the king, it becomes clear to the king (and to us, the readers or listeners) that Bharata is profoundly wise. Rahugana is deeply humbled, submitting himself to this unlikely sage for spiritual guidance. ${ }^{23}$ And what Rahugana learns from him is what Bharata had learned by direct experience through the practice of devotional yoga that led him through the life of a nonhuman animal - as a deer-while retaining the previously developed consciousness of a yogi. He experienced directly that the transmigratory mechanism of nature (prakriti) can, depending on the actions (karma) and disposition (guna) of living beings, bring a human being into a nonhuman body and vice versa. He also learned that all bodies of living beings are only superficially different, their physical elements all coming from the same source, the earth. Further, he learned that the living beings, all of the same non-material quality, are each accompanied by the one higher self (paramatman) and, says Bharata, it was by virtue of his resolute devotion to this higher self, whom he identifies as Krishna, that he has come to this comprehension of reality (BhP 5.12.8-15).

In contrast to Jada Bharata's heightened sensitivity to living beings' conditions is the initial insensitivity of the king, whom the devotional yogi chides for arrogantly posing as the citizens' protector. Although not explicitly charged with harming animals, Rahugana displays a materialistic disposition as a ruler implicated in a life of violence and thus in the crippling bondage of retributive karma. But now, having met and heard from Jada Bharata, all this has changed. As a conversion story, this episode represents a major theme of the Bhagavata Purana, namely, that encounters

\footnotetext{
${ }^{23}$ In contrast to the dharma-bull, to whom the Bhagavata Purana gives voice, the deer cared for by Bharata and then the deer that Bharata becomes are both silent. Yet as the silent, apparently deafmute Jada Bharata is challenged by the proud king, he speaks forth the Bhagavata's bhakti message, indicating that the higher truth of right action is often voiced best by those who are socially marginalized and who have an affinity with nonhuman animals.
} 
with spiritually enlightened and caring sages can be profoundly transformative. ${ }^{24}$ By such good fortune, one can undergo the sort of change of heart that sets one on the devotional path of care, radically dislodging the embodied being's false sense of identity and possessiveness (ahamkaraliterally "I do"; mamata, "mine-ness"). Such a devotional (bhakti) path is the attentive practice previously mentioned, whereby the ultimate good of all living beings becomes the measure of right action, in a spirit of service. ${ }^{25}$ All beings are seen as eternal, infinitesimal in size and power, and unique instances of the one all-sentient, relational being, bhagavan (the same as paramatman), characterized by infinite qualities and virtues and having an exquisite, atemporal form with three core features - eternity, cognizance, and felicity (sat, cit, and ananda). Jada Bharata's transformative outreach to the benighted king thus indicates a political dimension, namely, that by virtue of higher vision with respect to living beings, the truth that devotional yoga yields for its practitioner can positively affect the world and stands to prevail over blind, ignorant worldly coercive power, since the devotional yogi participates in a higher spiritual order that governs the universe.

A final implication of the story for us to note has to do with a deeper dimension of bhakti-yoga, namely the sense of absence and loss as a wellspring of intense devotional emotion. Bharata's initial care for the young deer points toward this notion. The text indicates that whenever the fawn would venture away from the sage's hermitage, Bharata would be stricken with anxiety for her well-being. His expressions of longing in "separation" anticipate the later full elaboration, in the Bhagavata's Book 10, of Krishna's beloveds in Vraja pining for him in his absence. Bhakti in this tradition is particularly characterized by the sense of intense devotional longing that Krishna-bhaktas experience for Krishna when he seems to be absent from his land of cows, Vraja (Holdrege 2013; Schweig 2013). Vaishnavas regard

\footnotetext{
${ }^{24}$ This theme is also present in the Mahabharata, typically in the context of dharma-as-virtue; at times, it is represented such that a sage_-already advanced in spiritual knowledge-learns an essential lesson from a socially marginal person. See Dalmiya's (2016, pp. 108-114) summary and analysis of the Mahabharata's story of sage Kaushika, who learns "relational humility" from a housewife and then a butcher.

${ }^{25}$ The Bhagavad-gita (3.25) also features bhakti as a practice aiming toward benefitting all beings, through "detached action," contrasting this with the attached action of the "nonlearned." Thus, right action is identified with an attitude, namely detachment from the results of action.
} 
Vraja as the place where all creatures are absorbed (being situated in the state of samadhi, the goal of yoga) in relational care for Krishna-and thus care for each other-and Krishna is equally absorbed in relational care for all creatures.

\section{Reverence in the Bhakti Paradigm}

To further appreciate the bhakti paradigm for animal ethics, let us consider the notion of reverence. We recall that the final component of the fivefold yoga observances (niyama) is ishvara-pranidhana, devotion or submission to God, a practice that leads to samadhi, which we defined as "singular absorption of one's awareness in the reality of one's non-physical identity." 26 But unlike classical yoga, wherein the emphasis is on emotional restraint to realize samadhi, bhakti celebrates salvific emotional awakening to non-temporal being and to divinity as both the means and the goal of devotional life. In its most developed form, such devotionally emotional awakening is also regarded as samadhi that goes beyond mere awareness of one's non-physical identity to absorption in love and service to God. ${ }^{27}$

With such theistic orientation, Hindu bhakti tradition apparently runs counter to a strong current in the contemporary Western zeitgeist-one of suspicion, if not outright rejection, of theistic grounding for ethical deliberation and practice. As moderns, we tend to dismiss the notion that the discernment of right action and the good should proceed from divine revelation. In the West, the questioning of divine authority in moral issues goes back to at least the Euthyphro dialogue of Plato, with its portrayal of divine command theory and its dilemma over the locus of the good. Is an act good because it is commanded by God (or gods), or is good commanded by God (or gods) because it is good? Later Christian reflection

\footnotetext{
26 "A practice that leads to samadhi" is an important understanding indicated in Patanjali's Yoga Sutras. Yet the text also makes clear that ishvara-pranidhana is not merely instrumental to higher yogic accomplishment, for it is also itself the goal. In other words, ishvara-pranidhana is itself the state of samadhi, as becomes thoroughly clear in the Bhagavata Purana. I am grateful to Graham Schweig (personal conversation) for clarifying this point.

${ }^{27}$ In the Bhagavata Purana (11.12.12), Krishna uses the term samadhi to describe the intense devotional absorption of his beloveds, the Vraja cowherdess, in thinking of him, "as sages enter into samadhi, like rivers flowing into the ocean."
} 
on this issue will speak of voluntarism (the creation of morality out of God's free will) and intellectualism (God's discernment of eternal moral truths, valid for both God and creatures). For us to note here is that the bhakti paradigm foregrounds not so much God's will as God's preference in matters of moral decision-making, leaving human beings free choice to act or not to act in pursuit of, or in harmony with, this preference. This understanding resonates with a third alternative to voluntarism and intellectualism, namely, that God is essential to morality because morality flows from his motives, which are components of his virtues, which in turn point to his personhood (Zagzebski 2004, pp. 185-206). This understanding preserves, and indeed celebrates, free choice as the basis for authentic love for God-as-person. ${ }^{28}$

This third option, expressed in terms of divine motive and preference, may point a way toward appreciating and recovering a core value of the European Enlightenment, namely reverence. As Susan Neiman (2008, p. 112) points out, contra popular opinion that Enlightenment thinkers were religion bashers, "The Enlightenment took aim not at reverence, but at idolatry and superstition." In a similar spirit, Indian bhakti traditions, especially from the sixteenth century onward, tended to question meaningless observance of prescribed rituals (excesses in the name of dharma observance) and valued reason as a support for cultivating a sense of valuing and revering the world as divine creation. ${ }^{29}$

\footnotetext{
${ }^{28}$ Taking the Bhagavad-gita as a point of departure for elaboration on this point, there are statements suggesting both sides of the dilemma. On the one hand, out of his free will God creates the world (e.g., 9.7; 10.8), and on the other, out of a sense of duty he acts in this world to give example for human behavior in the world (3.22-24). I would suggest, however, that divine preference is indicated early in the Gita, when Krishna emphasizes the value of yajna as the means for becoming free from the bondage of karma (3.9). A key phrase here is tad-artham karma...samācara-"perform action well, for that purpose," where "that" refers to yajna, which Vaishnava Hindus identify as an embodiment of Vishnu. The artham - "purpose"-is the key term suggesting divine preference, "Vishnu's purpose." Krishna also indicates that he does not resent those who ignore him; rather, he simply gives them what they want and deserve (7.21; Goswami 2015, p. 36) Further, in relation to divine motives, we may note the Gita's reference to "higher nature" and "own nature," param bhavam; sva-bhava $(7.24 ; 9.11 ; 8.3)$, as its way of expressing this notion, along with several statements indicating divine wish for alienated souls to take final refuge in him.

${ }^{29}$ See Prentiss (1999, especially pp. 25-42), for a discussion of differing historiographies and theories of bhakti as a movement. My generalizations here are intended only to highlight bhakti in contrast with dharma and yoga. One identifier for bhakti literature is its use of vernacular languages rather than Sanskrit; yet there is also a rich body of bhakti literature in Sanskrit as well, among which
} 
Yet already in the ancient Bhagavad Gita, Krishna famously questions ritualism, valuing instead simplicity rooted in devotion. A particularly telling statement relevant to this and our general subject can be seen as Krishna's broad invitation for all to practice bhakti, engaging with the simplest of ingredients provided by nature: "When one dedicates to $\mathrm{Me}$ with devotion a leaf, flower, fruit or water, I accept that devoted gift from a dedicated soul" (Goswami 2015, p. 182; Bg. 9.26). Thus, the theistic framework of bhakti ethics, while holding human beings responsible for their actions, emphasizes open opportunity-as an invitation-to serve divinity. Such divinity is comprehended as the supreme person who, as "superself" or "oversoul" (paramatman) within the constraints of the temporal realm, bestows sanction and power to act. Such divinity guides creatures toward freedom in action that is grounded in a progressive unfolding of value and meaning rooted in love.

Just how the relationship between choice and divine guidance in the bhakti paradigm unfolds is shown in an eighteenth-century devotional song from the Chaitanya Vaishnava tradition. In his Prema-bhaktichandrika (10), Narottamdas writes (in Bengali) sadhu-shastra-guru-vakya chittete koriya aikya, satatam bhasibo prema-majhe. "Bringing the words of the devotees, of the scriptures, and of the preceptor into a single understanding in my heart, I will float amidst love" (Babaji 2010, p. 115). This suggests that devotees (bhaktas) come to understand how best to act after consulting with fellow practitioners as well as with their spiritual guides and relevant sacred texts. These resources combined are considered effective in attuning oneself to guidance from paramatman within the "heart" or core of one's being. Further, and importantly, such attunement affirms the rightness of action in relation to living beings through the recognition that all life, being not reducible to matter, calls for attentive reverence and appropriate care. Thus, the Enlightenment project of recovering reverence-which turned particularly to nature as the objective manifestation of divine order and perfection-may be seen as enhanced by the bhakti paradigm, in such a way that reverence is appropriately extended to all living beings.

the Bhagavad-gita and Bhagavata Purana have enjoyed prominence and continue to do so in the present. 


\section{Ethics of Care and Hindu Animal Ethics}

With the foregoing discussion of the three paradigms — dharma, yoga, and bhakti-in relation to ethical thought, we can return now to our central question of this chapter: In what ways may Hindu animal ethics be best understood in relation to Western animal ethics discourse, particularly in connection with cow care, a major concern of many Hindus? Contemporary animal ethics discourse has, with greater or lesser persuasiveness, over recent decades, drawn points of argument from general ethics (including varieties of deontic and virtue ethics) to establish compelling, reasoned grounds for nonhuman animal protection, with special concern to establish nonhuman animals as rightly possessing moral status. However, some ethicists have argued that standard forms of normative ethics discourse (deontic, consequentialist, virtue) have proven inadequate to the task of bringing significant and lasting reform to behavior within human society. Similarly, persons concerned with animals have been dismayed by the lack of substantial positive change with respect to human-nonhuman animal relations despite the high volume of animal ethics discursivity in recent decades (Donovan and Adams 2007, pp. 1-20; Donaldson and Kymlicka 2013, pp. 1-11).

One response to these disappointments has been the rise of the "ethics of care" from the early 1980 s and, in relation to animal ethics, from the late 1990s. Both currents share an identification with feminist concerns, characterized by pioneer author Carol Gilligan as articulating and practicing a "morality of responsibility," contrasted with the masculine inflected "morality of rights" (Donovan and Adams 2007, p. 2). Vrinda Dalmiya (2016, pp. 4-5) identifies five themes characterizing the metaethical framing of care ethics, namely (1) relationality (acknowledgment of the embodied condition of all subjects of moral action); (2) recognition of needs (addressing often conflicting needs of corporeal and hence vulnerable, selves); (3) affectivity (the recognition that emotions have an important place in moral decision-making); (4) contextualism (the awareness that moral judgments always take place in specific relational contexts); and, finally, (5) responsibility (the recognition of "moral remainders"-of feelings such as guilt and uncertainty regarding inevitable limits to one's capacity to respond). More specifically referring to the ethics of care in 
relation to animals, Donovan and Adams (2007, pp. 3-4) identify attention as a "key word in feminist ethic-of-care theorizing about animals." Along with the importance of attention to individual suffering animals, attention is necessary also to "the political and economic systems that are causing the suffering."

To gain a sense of how these themes might unfold in the context of Hindu animal ethics, I return briefly to the Mahabharata episode mentioned earlier, in which King Yudhishthira insists on having a companion dog accompany him to heaven. In this account, the king acknowledges a relationship with the dog such that he does not regard embodiment as a dog as an impediment to sustaining the relationship, despite traditional Indian (especially brahmanical) disdain for dogs. He therefore answers to the dog's need, which is to be in the king's protection. Further, the king acknowledges his own feelings for the dog as a result of the dog's demonstration of unwavering loyalty; the king takes account of the situation's context to the extent that he is willing to forego entrance into the heavenly realm, in favor of preserving the caring relationship with the dog. Finally, King Yudhishthira takes responsibility for his decision, whatever faults might arise as a result. As for attention, we can appreciate that it is present in all these five themes, in such a way that Yudhishthira is attentive to the individual dog and, at the same time, he is resistant to the political current that would reject his act of care.

For us to note in particular from this king-and-canine story is how a broad care ethics perspective-initially limited to moral concerns among human beings, exemplified in the mother-child relationship-may be appropriately applied to human-nonhuman animal relationships. And the key to this extension is the simple, common awareness that humans can and do have relationships with specific animals, relationships involving various sorts of reciprocity and, typically, active caring on the part of humans for such animals. Such relationships are usually seen in human interaction with companion animals_-pets or horses-but they can and do extend to other animals as well.

Yet an important issue arises in consideration of animals in the context of care ethics. Whereas care ethics in the human sphere is (generally) free from notions of ownership on the part of moral agents regarding their subjects of care, animals are mostly regarded as owned - in the possession 
of - their carers or of persons for whom carers work. This applies especially (but not only) to animals we denote as "domestic" or "domesticated" and to farm animals, which are generally confined to particular humandemarcated spaces. However, returning once more to Yudhishthira, the story suggests that the king's purpose is not to remain the dog's master and controller; rather, it is to bring him to a state of freedom (represented in the Mahabharata context as "heaven"). Thus, the implication is that the king, embodying dharma in its deepest sense, aims to acknowledge the non-material reality of the dog as a conscious, non-temporal being with inherent value and pursuing its need for freedom.

Going a step further, we may imagine Yudhishthira, as he ascends the mountain with the dog, aspiring for the yogic state of freedom (kaivalya). As we discussed earlier, in its deepest sense, kaivalya of classical yoga means facilitating not only one's own freedom but also the freedom of other beings, such that relationality is enriched among all. In fact, the term kaivalya is also employed within the bhakti paradigm, wherein it refers to selfless devotion to the supreme person, bhagavan, who is the very embodiment of complete freedom. ${ }^{30}$ Also, in the Bhagavata Purana, King Yudhishthira is celebrated as such a selfless devotee, suggesting that his actions are entirely oriented toward responding favorably to divine preference. ${ }^{31}$ By virtue of his identity as king, with responsibilities to all citizens of the kingdom, his engagement with the dog may be seen as conforming to the didactic function of leaders that Krishna refers to in the Bhagavad Gita: "Whatever the greatest one does, common people do just the same, following the standard he sets" (Goswami 2015, p. 162; Bg. 3.21). In this case, the king teaches not only that people should respect and appropriately care for animals. Arguably, he also teaches that animalsin particular domestic animals - are appropriately regarded in important ways - though not in all ways assumed in common usage today-as citizens, or as citizens-in-the-making. As citizens or aspiring citizens, at least certain animals can be regarded as members of the moral community such

\footnotetext{
${ }^{30}$ Krishna instructs his friend Uddhava on the nature of the supreme person in the Bhagavata Purana's Book Eleven, including that he is kevalänubhavananda-sandoha - "the aggregate of the experience of the bliss of kaivalya" (Bhagavata Purana 11.9.18).

${ }^{31}$ For example, Bhagavata Purana 1.8.5 refers to Yudhisthira as ajāta-śatru- "he whose enemy is not born" (he who has no enemies).
} 
that a central principle of bhakti can be realized with maximum inclusiveness, namely seva - attentively caring devotional service as an integral feature of bhakti practice (sadhana). By such devotional service, "relational humility" (Dalmiya 2016, pp. 2-3) - the disposition that makes effective caring and its resultant knowing possible—is realized.

\section{Animal Citizenship, Community, and Bhakti}

We have encountered a possible problem in applying the ethics of care to human-nonhuman animal relations as opposed to human-human relations, namely the issue of ownership. It is clearly the case that present-day rampant and pervasive abuse and slaughter of farm animals for human use and consumption are deeply rooted in the supposition of ownership. Recognition that animal ownership drives and sustains animal abuse has led to a sharp distinction between "welfarist" and "basic rights" approaches to animal advocacy. ${ }^{32}$ According to prominent animal rights advocates, any apparent success in raising animal welfare standards of treatment serves only to legitimate and intrench the system of animal exploitation, reaffirming the status quo of animal ownership for human use and consumption. ${ }^{33}$ By this reasoning, from an animal rights perspective, the objection may be raised that even if animals are not subject to slaughter and consumption and they are provided ideal living conditions, the very fact that such animals are held as property (and are even only minimally confined) means that their care is compromised. The "owner" of an animal, no matter how caring she or he may be, remains always in a position of power over the animal, ultimately the power of life and death. Such an "owner" may decide-even despite feelings of affection toward, say, his or her family cow-to sell her for slaughter, pleading inability to continue financially

\footnotetext{
${ }^{32}$ As noted by Donaldson and Kymlicka (2013, pp. 3-4), a third, "ecological holism" approach is similarly inadequate for effectively protecting animals. "In this case, the interests may be less trivial [than those that limit the scope of welfarism]. Nevertheless, ecologists elevate a particular view of what constitutes a healthy, natural, authentic, or sustainable ecosystem, and are willing to sacrifice individual animal lives in order to achieve this holistic vision."

${ }^{33}$ See Francione (2004), quoted in Kansal (2016). See the latter for a relevant legal discussion on animals as property in the context of animal welfare law in India.
} 
maintaining the non-productive cow. ${ }^{34}$ Such cases (which are more the rule than the exception) lead into the question, what can be said about Hindu animal ethics as an inflection of care ethics? Is the welfare/rights distinction appropriate and, if so, where would Hindus locate themselves on this map? To consider these questions, it will be helpful to return to our main subject in relation to Hindu animal ethics, namely care of cows.

From a responsible Hindu perspective, there is no doubt that presentday animal "husbandry" (mal)practices with bovines exceed all boundaries of decency and morality. Neither is there a question of animal welfare (even if legal welfare standards are met) in animal husbandry establishments, what to speak of there being any consideration of rights for the cows. As we have noted in Chapter 4, the massive dairy industry in India functions only on the basis of either releasing dry cows to fend for themselves (anna pratha), giving them to a cow shelter, or sending them for slaughter. Conditions for bulls are almost always worse, invariably destined for slaughter at a very early age (unless kept for reproduction). What, then, might be appropriate criteria for identifying a model of care for cows according to Hindu understanding, and would such criteria withstand the insistence of some animal activists - abolitionists - that the only proper relationship of humans with animals can be one in which humans make no use whatsoever of bovine products?

To this last question, the answer from the position of abolitionist and animal rights activism may well be, "Whatever criteria Hindus may set will surely be unacceptable. The criteria of care for cows by Hindus will surely allow for taking the cows' milk (even if only excess milk) and castrating the bulls (even if under anaesthesia) to work them as oxen, both of which involve various forms and degrees of violence. None of these could pass as acceptable ethical behavior, because any such use is unnecessary and exploitative." Cow care rejection would be rooted in the rejection of animal ownership and the concern that bovines are involuntarily confined, cows are involuntarily milked, bulls are involuntarily engaged in work, and bovines are subjected to controlled and forced breeding by artificial means.

\footnotetext{
${ }^{34}$ See Govindrajan (2018, pp. 65-66, 84-87) for a detailed description of such a case she witnessed in an Indian Himalayan village community. In this case, it was a "Jersey" (non-indigenous cow) for which, although the owner felt it was probably "not a sin to let it go," she had felt strong affection to the point of tears when the cow was taken away (for slaughter) after being sold.
} 
Indeed, from this abolitionist perspective, the practices of cow care, however much care, attention, and affection would be given to cows, is fundamentally exploitative and is, therefore, appropriately compared with human slavery (Clark 2011; Wise 2011, p. 20; Schuster 2016, p. 218). In this understanding, cow care-however conscientiously practiced it may be-partakes in moral discrimination on the basis of species, which is rooted in anthropocentrism. It is akin to discrimination on the basis of race, sex, gender, class, ethnicity, or sexual preference. This is a position that stands firmly for radical human lifestyle change, to a strictly vegan diet (in particular for people of the Global North with their greater choice of diet and necessary economic means). ${ }^{35}$

Although Hindus would generally question the notion that cow care is inherently exploitative, important features of the vegan stance can be appreciated by conscientious Hindus-in particular, veganism's commitment to foreswearing all unnecessary violence. Practices that minimize violence, especially practices related to food production and consumption, are certainly praiseworthy and desirable. The abolitionist position gives good reason for Hindus to reconsider their consumption of cow milk, even from cows that are well cared for throughout their natural lives. Could it be that the amount of milk one has become habituated to consume is disproportionate to need, assuming there is a need? Could it be that one is unnecessarily subjecting cows and bulls to one's own purposes, thus violating these beings-in-animal-bodies and thereby violating the principle of nonviolence as the highest dharma (as per Mahabharata 13.117.37-38)? Further, from the perspective of the bhakti paradigm (which, as we saw, values responsiveness to divine preference), does it not happen that, in the name of pleasing Krishna with lavish dairy-based food offerings, one may be overindulging one's own predilection for these? If misconstrued,

\footnotetext{
${ }^{35}$ For one representation of what he calls the "vegan imperative," see Steiner (2013, especially pp. 195-215). He defines ethical veganism as "the principle that we ought as far as possible to eschew the use of animals as sources of food, labor, entertainment, and the like, inasmuch as eating, enslaving, or otherwise doing avoidable violence to one's kin is fundamentally wrong" (p. 206). Responding to the argument that the taking of milk and eggs for human consumption "need not take the form that it currently takes," Steiner concedes that this is technically correct. "But it misses the larger point that using animals as delivery devices for food (and clothing, etc.) to be consumed by humans, viewed from the standpoint of cosmic holism and in the light of felt kinship, is a perverse idea" (p. 213). This view may be contrasted with that of Cochrane, quoted later in this chapter.
} 
the bhakti orientation can spawn excesses on the side of veneration that results in "extreme transcendentalism" that can obstruct clear thinking and action for genuine care of cows. ${ }^{36}$

The analogy of cow care with slavery also calls for consideration. In its favor, the slavery analogy calls attention to what may be understood as an absence of "consent" on the part of bovines-consent of cows to being milked or consent of bulls to being worked. At the same time, it may be right to consider in what sense consent might be applicable to nonhuman animals (and what are the indicators of consent or lack of consent for bovines). ${ }^{37}$ While it is true that human slavery and the condition of animals have been compared since ancient times (Clark 2011), as with all analogies, there are limits to this one. So, for example, enslaved humans have been intentionally prevented from becoming literate as a key means of keeping them in bondage. But unlike enslaved human beings, there is no reason to suppose that bovines-as long as they are in bovine bodies-would ever be able to use human language and thus adopt the life of full human citizenship as is understood today. Put differently, it is not necessarily "speciesist" to recognize differences among species while making ethical judgments with respect to treatment and care thereof. ${ }^{38}$

\footnotetext{
${ }^{36}$ In another, related context, David Haberman (2006, p. 135) identifies as "extreme transcendentalism" a tendency of some Hindus to ignore the polluted condition of sacred rivers, claiming that their sacrality cannot be compromised by temporal conditions. In the name of care for bovines considered "sacred," I have seen some shelters in which cows are clearly underfed or unduly tethered.

${ }^{37}$ In her Kantian account of human interaction with animals, Korsgaard (2011) argues that in the absence of the ability to perceive consent to various treatments by animals, the plausibility of consent must be accepted where animals are well treated and not subjected either to experimentation or early death. Donaldson and Kymlicka (2013, pp. 111-112) share an interesting account of "dependent agency" among cows at the family farm of Rosamund Young (in Worcestershire, UK) (Young 2003 , pp. 10, 52) that emphasizes the individuality of the cows in their choices regarding diet and movement.

${ }^{38}$ For a discussion of speciesism, anthropocentrism, and questions of similarity and difference between/among human and nonhuman animals, see Freeman (2010). Freeman identifies two "natural" moral principles of humans, namely cooperation to garner social support and moderation for bringing ecological balance. She urges that moderation should be "based on the idea of taking only what we need for our basic survival, complementing the principles of deep ecology, with any excess acts of harm constituting exploitation and a breach of ethics" (p. 22). This has a striking parallel in the ancient Ishopanishad statement (v. 1), albeit without the latter's strongly theistic orientation: "This visible world, and whatever exists beyond perception, is under the control of the Lord. Because of this you should enjoy only what is allotted to you by the Lord through karma. Do not hanker for more than that. Whose property is it?" (Swāmī 2006, p. 13, trans. of the eighteenth century Vaishnava commentator Baladeva Vidyabhūșana’s rendering of the text).
} 
This is not to endorse a premise of moral hierarchy that invites speculation on "acceptable levels of animal exploitation" (Donaldson and Kymlicka 2013 , p. 4). Rather, it challenges us to recognize that we live with multiple differences (not "higher" and "lower," but having difference) among species, and these differences may be morally relevant for ethical behavior of humans in relation to nonhuman animals. As Alasdair Cochrane (2012, p. 11) points out, recognizing differences between species and their capacities impels us to consider that,

some practices that are objectionable when done to humans are not objectionable when done to animals: keeping an animal as a pet is quite different from keeping a human as a slave; use animals to undertake certain kinds of work is quite unlike coercing human beings to labor; buying and selling animals is quite unlike trading human beings, and so on.

One distinction is particularly relevant for our discussion, namely among domestic, wild, and "liminal" animals_-those that are brought into human community, those that are quite independent of humans, and those that live in partial relation to humans (Donaldson and Kymlicka 2013). Indeed, making these distinctions may lead us to entertain a reconceptualization of domestic animal political identity to better accomplish proper care. As we tend to locate citizenship and slavery on opposite ends of a polarity of civic freedom and bondage, let us consider Sue Donaldson's and Will Kymlicka's (2013) novel proposal, namely, to extend the concept of citizenship to be inclusive of domestic animals. ${ }^{39}$ Donaldson's and Kymlicka's point of departure is that animal rights theory, while valid and important, has focused exclusively on negative rights-basically the right of animals not to be harmed. While this thinking has driven important advances in animal advocacy, "[t]he animal advocacy movement has nibbled at the edges of this [global] system of animal exploitation, but the system itself endures, and indeed expands and deepens all the time, with remarkably little public discussion" (pp. 1-2). Drawing inspiration from

\footnotetext{
${ }^{39}$ As they propose "citizenship" for domestic animals, Donaldson and Kymlicka propose "sovereignty" for wild animals and "denizenship" for liminal animals. Such categories and designations of community membership are intended to recognize animals "not just as individual subjects entitled to respect of their basic rights, but as members of communities-both ours and theirs-woven together in relations of interdependency, mutuality, and responsibility" (2013, p. 255).
} 
the disability movement, the authors argue that a conceptual framework of citizenship can and should be conceived for inclusion of domesticated animals and that this is possible if one sets aside the arbitrary limitations imposed on citizenship by a cognitivist interpretation of required capacities for citizenship. This involves a change in the conception of citizenship that "recognizes that we are all interdependent, and experience varying forms and degrees of agency according to context, and over the life-course" (p. 108). It then becomes possible to recognize that domestic animals (including bovines) possess, in their own ways, the three capacities specified as required for citizenship. Domestic animals demonstrate (1) the capacity to have a subjective good and the ability to communicate it; (2) the capacity to participate (specifically, by sheer presence in human settlement, as opposed to being made invisible, as in the modern meat industry); and (3) the capacity for cooperation, self-regulation, and reciprocity (pp. 103, 108-122). ${ }^{40}$ Among nine specific areas of presupposition for citizenship discussed by the authors, we can give attention to four, with respect to cow care ${ }^{41}$ : (1) mobility and the sharing of public space; (2) use of animal products; (3) use of animal labor; and (4) sex and reproduction (p. 123).

Regarding mobility and sharing of public space, the authors conclude that animals, like humans, need "sufficient mobility, not unlimited mobility. This need may be met with large fenced ranges and pastures, and parks," and restrictions on mobility would be justified by the need for protection of the animals and/or humans. Yet justifiable restrictions would, in such a vision of citizenship, "always have a provisional status—open to appeal, negotiation, and ongoing evolution. We simply don't know what humananimal society might eventually look like under these conditions" (p. 130). Bovines should have large areas of open space for grazing, but as we have

\footnotetext{
${ }^{40}$ So, for example, domestic (including farm) animals (1) show preference, interests, and desires, through vocalizations, gestures, movements, and signals - communications that humans can and should attend to; (2) can, by their sheer presence, be advocates and agents of change or show resistance to work; and (3) can experience a wide range of emotions, including empathy, trust, altruism, reciprocity, and a sense of fair play (Donaldson and Kymlicka 2013, pp. 108-117).

${ }^{41}$ The other five areas are: (1) basic socialization; (2) duties of protection; (3) medical care; (4) predation/diet; and (5) political representation.
} 
seen in the previous chapter, in India such conditions have become the exception. And yet, the fact that cows are seen freely roaming the streets of village, town, and urban areas is a striking indicator of how human-animal society could be imagined if these cows would be properly cared for (see Fig. 5.1). ${ }^{42}$

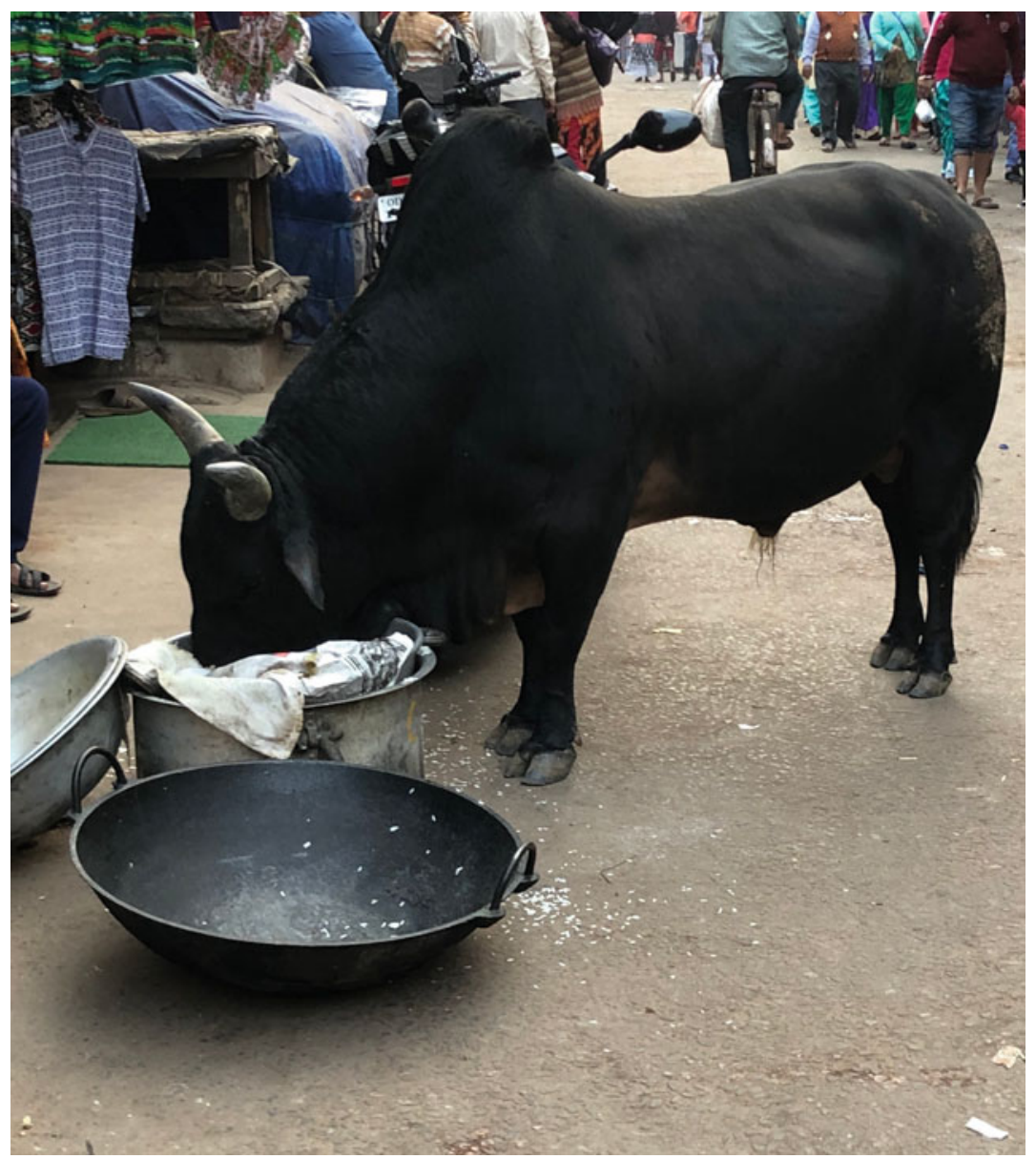

Fig. 5.1 A street-wandering ox in Puri is given a full pot of rice by a shopkeeper 
Use of animal products. The Zoopolis authors argue that to distinguish between (legitimate) use of animals and their (illegitimate) exploitation is comparable to seeing what forms of use of humans are "consistent with full membership in society, and what forms of use condemn people to the status of a permanently subordinated caste or class" (p. 134). They reject the idea that any use is necessarily exploitative or that use inevitably leads "down a slippery slope to exploitation." Rather, they suggest that "a refusal to use others-effectively to prevent them from contributing to the general social good — can itself be a form of denying them full citizenship" that is as problematic as it is for one group to be kept as a permanently subordinated caste. Significantly, the authors give as example the careful sheering and collection of wool from sheep that due to domestication and breeding can no longer shed their wool naturally: To not (carefully) sheer them in timely fashion would be a form of abuse and to not make use of their wool "begins to look perverse" (pp. 136-137).

What particularly increases the danger of exploitation is commercialization of the product or products in question, and this is certainly a major-arguably the-issue with respect to cow milk. The ideal is for there to be village culture wherein cow milk that is truly surplus over calf feeding would be highly valued by the human village members and, in accordance with the bhakti paradigm, would offer it (and the other dairy products and derivative preparations) as delicacies to temple or home images, especially of Lord Krishna, the thus sanctified offering (prasada) to be subsequently given mainly to human children. The Zoopolis authors point out that the considerable difficulties involved in maintaining cows in a non-exploitative way would result in a highly reduced bovine population (p. 139). In fact, if this were to happen, it could be a blessing for the global natural environment that currently suffers acutely from excessive animal—especially bovine—husbandry for commercial purposes. Further,

\footnotetext{
${ }^{42}$ It could be argued that when bovines become strays, they are forced out of the category of domestic animals to become liminal animals. Yet strays must be distinguished from what might be called "day wanderers"- bovines with human owners who are set out during the day to wander (usually in village or semi-urban areas in India) and return to their owners in the evening. One can often see such "day wanderers" being provided some food by particular neighbors of their owners, and they are known to quickly learn which homes they can expect to receive food and will then stop at those homes each day.
} 
for Hindus, rarity of cows could serve to enhance the sense of their venerability and therefore be conducive to their proper care.

Use of Animal Labor: Certain animals, such as certain dogs and donkeys, can with little training perform such activities as shepherding and protection. Donaldson and Kymlicka invite readers to imagine non-exploitative arrangements for involving such animals in types of labor that come naturally to them. At the same time, they call attention to the danger of animals' "adaptive preference" being misread as behavior that is accepting or welcoming of their labor, when it is actually the result of training that is thinly disguised coercion (p. 141). As we saw in Chapter 4, oxen trained for work have been perceived by their trainers as showing eagerness to exert themselves in drawing a plow or a cart. Whether this would be regarded as adaptive preference would be a matter of debate, but it is clearly the case that bovines, both male and female, need to be given opportunity for sufficient regular bodily movement and exercise, an opportunity usually denied in cow shelters. ${ }^{43}$

Sex and Reproduction: Domestication is fundamentally involved in reproduction control, usually with the aim to increase certain traits in animals considered favorable or useful for humans and to reduce or eliminate traits considered unfavorable. That humans see such practices to be morally acceptable is deeply ingrained; one could argue that such practices fundamentally counter any notion of nonhuman animals being seriously regarded as co-citizens with humans. However, the Zoopolis authors point out that regulation of sex and reproduction occurs in several ways both within human society and wild animal societies and, of course, is also regulated by external factors in all cases. Also, to allow unrestricted breeding among domestic animals such as bovines would be against their own interests, as it would lead to a breakdown of the conditions in which they can live. With bovines, an important starting point for reproduction regulation in a Hindu care ethics milieu would be a reduction of reproduction for cows, unburdening them of forced pregnancy in the interest of increased milk production. Related to this could be to abandon crossbreeding for

\footnotetext{
${ }^{43}$ That bulls and oxen should be treated gently is indicated (in a rather curious way) in the Mahabharata, wherein the only exception to the rule that they should not be driven with goad or whip is when engaged in plowing the ground in preparation for a ritual sacrifice (Ganguli 1991, p. 88; Mahabharata 13.69).
} 
increased milk production. This is a major issue in contemporary India where, as we saw in Chapter 4, there is growing concern to preserve and recover indigenous bovine breeds to counter the practice of crossbreeding indigenous with non-indigenous — especially European-bovines.

\section{Dharma-Based Communitarianism}

Surely from this very brief sketch of four areas of presupposition for citizenship, we can only begin to picture a citizenship framework that is inclusive of animals, particularly of cows. And while this framework is predicated on an animal rights orientation to animal activism, my proposal is that the ethics of care approach, with its positive attention to relationship, needs, feelings, context, and responsibility, can serve to better comprehend how animal citizenship can become a reality among individual humans and communities. Yet citizenship, as we understand it today, has no meaning without the existence of a state, the modern locus of political activity and political background of community. We may ask what sort of political theory would best respond to and complement a Hindu-especially a dharma, yoga, and bhakti-based_-animal ethics. Here I will put forth communitarianism as a starting point for our purposes, hastening to add that "communitarianism" is not to be confused with "communalism," the term used in contemporary India to describe the divisive socio-political and religious force seen as cause and perpetuator of conflict in India, especially between Hindus and Muslims or between Hindus and Christians.

As a political theory, communitarianism is typically contrasted with utilitarianism and with liberalism. Unlike utilitarianism, communitarianism derives the common good from the shared norms of particular societies, and unlike liberalism, communitarianism urges active involvement by the state in promoting what is determined to be the common good, over the rights and liberties of individuals (Cochrane 2010, p. 91). In applying communitarian political theory to questions of animal care, a standard formulation of communitarian thought can be problematic in several ways. Broadly speaking, to establish principles for determining what constitutes just negative regulation (regulations preventing injustice 
and abuse of animals) can face knotty questions regarding human rights (Cochrane 2010, pp. 76-91). ${ }^{44}$

I propose, rather, a dharma-based communitarianism as an alternative approach, one that is necessarily inflected with the devotional vision of the Bhagavata Purana text and the culture it represents. ${ }^{45}$ Bhagavata-dharmabased communitarianism would have as its basis for deliberation and decision-making the discernment of applicable principles rooted in the three paradigms previously sketched, namely dharma, yoga, and bhakti. Application of such principles may not be possible in entire states, but in particular communities within states application could occur with the guidance of persons who are recognized by such communities as qualified to do so. We recall (from Chapter 2) the Bhagavad Gita's statement (3.21), "Whatever the greatest one does, common people do just the same, following the standard he sets," and we recall that King Yudhishthira, by his care for the dog, proves to be an exemplar of such a "greatest one," as does Bharata in his concern for ants (discussed earlier in this chapter). The Bhagavata Purana offers several such model practitioners of bhagavata dharma (including Yudhisthira), elaborating extensively on their qualities and qualifications as leaders of society. ${ }^{46}$

\footnotetext{
${ }^{44}$ Cochrane (2010, p. 91) summarizes the challenges that communitarianism faces with respect to animal care: "Firstly, any attempt to promote the shared values and norms of a community raises the question of whose values and norms are to be promoted. For as we have seen, states contain a number of different communities. Secondly, this is important in the case of animals because often states contain communities which have quite different attitudes and practices relating to animals when compared to those of wider society. Thirdly, one option for communitarian thinkers is to advocate 'multiculturalist' policies which allow communities to be exempt from general animal welfare standards. This allows for the goals and values of a range of communities to be respected and promoted. Finally, however, such policies are extremely controversial and have been objected to on the grounds that such practices cause real harm to individual animals, and because it is often unclear just which types of group warrant such exemptions and why."

${ }^{45}$ As noted in Chapter 2, the Bhagavata Purana, an early Sanskrit text of the Purana genre of sacred lore, thrives in popularity in the present day and is highly esteemed in learned Hindu circles. It is therefore, as well as for reasons of its intrinsic value, most appropriate to bring it to bear in this discussion of ethics in relation to animals in the context of political philosophy.

${ }^{46}$ One epithet of Krishna mentioned by Queen Kunti (the mother of Yudhisthira and the other Pandava brothers) is akinchana-gochara-"he who is accessible to persons who have no material claims" (BhP 1.8.26). Noteworthy in relation to cow care is that gochara (accessible) literally means "cow pasture." As in English, a cow pasture is also a "range," spiritually progressive persons, who make no claims of material assets, are "within the range" of Krishna's blessing (see also Chapter 2, footnote 30).
} 
To better grasp how a bhagavata-dharma-based communitarian political approach would work brings us to the notion of "anticipatory community." ${ }^{\prime 7}$ An anticipatory community must be sufficiently well defined through consensus regarding its values of animal care. Then a bhagavatadharma-based communitarian approach to political practice can serve such a community's purpose of standing for its values (in this case of animal care and more specifically cow care as we have envisioned it in its best form). On such a basis, the community would also be enabled to promote these values in the wider society (Cochrane 2010, pp. 74-78). A ready example of this approach may be seen in M. K. Gandhi's efforts to establish ashrams (hermitages) with such practices and ideals. As a current example, we have the Govardhan Eco Village, introduced in the previous chapter, and in Chapter 6, we will look at two similar communities, one in Bengal, India, and one in Hungary. In these cases, the "communitarian" spirit of governance have been based on similar bhagavata-dharma principles, such that all community members have chosen to abide by regulations that are supportive of the respective communities' values, particularly regarding animal care.

In the case of Govardhan Eco Village, one can discern a strong emphasis on pursuit of the four virtue-nourishing practices that we considered earlier, namely compassion, austerity, purity, and truthfulness. More specifically, these values are secured by explicit disavowal of all meat-eating, intake of any form of intoxicants (including tea and coffee), illicit sexual activity, and gambling. These disavowals are taken as the basis for the positive activities of care that constitute the community's vision of

\footnotetext{
${ }^{47}$ In Larry Rasmussen's (Christian-inflected) portrayal of "anticipatory community," such projects must be "intimate communities of moral nurture" in which the "seeds of an Earth ethic" must be planted and nurtured, to meet "adaptive challenges." He defines his term thusly: "Anticipatory communities' are home places where it is possible to reimagine worlds and reorder possibilities, places where new or renewed practices give focus to an ecological and postindustrial way of life. Such communities have the qualities of a haven, a set-apart and safe place yet a place open to creative risk. Here basic moral formation happens by conscious choice and not by default (simply conforming to the ethos and unwritten ethic of the surrounding culture). Here eco-social virtues are consciously cultivated and embodied in community practices. Here the fault lines of modernity are exposed" (Rasmussen 2013, pp. 223, 226-227).
} 
bhakti-centered life-the way of devoted service to the supreme person, Bhagavan, revered in this community especially in the form of Krishna. ${ }^{48}$

We thus come back to a key principle of the bhakti paradigm, namely discernment and response to divine preference. This principle is particularly highlighted and celebrated at Govardhan Eco Village in the practice of seva - attentive service to Krishna, situated in several shrines on the GEV land. Ever celebrating Krishna's identity as divine cowherd, GEV residents are keen to prepare a wide variety of vegetarian - including dairy-baseddelicacies for his pleasure. The dairy-based food preparations-mainly sweet preparations - use exclusively milk from GEV's own hand-milked cows, and these are ritually offered to Krishna at designated times each day. Following the offerings, the sanctified food is received and "honored" by the community members in community meals. This culinary practice encompasses the entire range of processes from farming and husbandry to cooking, ritually offering, and receiving the offering "remnants" (prasada), creating a cycle of engagement in which food becomes a central vehicle for spiritual as well as physical nourishment. This nourishment then translates into the performance of varied bhakti practices for self-cultivation and outreach, both of which are seen in the context of the dharma paradigm as enactment of nonviolent sacrifice, which takes the specific form of samkirtana-collective or congregational celebration of participation in divine activity (lila).

\section{Concluding Reflections}

I began this chapter with a survey of three Hindu paradigms of thought and practice in relation to animal ethics, namely the dharma paradigm,

\footnotetext{
${ }^{48}$ In considering this community's standard of four strict disavowals, Roy Perrett offers an interesting and relevant discussion on "moral saints." Noting a distinction in Western "commonsense morality" between ordinary and extraordinary morality, morality, narrowly conceived, is concerned with those rules that make human society possible. In contrast, "[ $t]$ he extraordinary ideals are concerned with what in ethics lies beyond morality so conceived: the supramoral. No one can be morally blamed for not realizing supramoral ideals. "In other words, an ideal like sainthood may be praiseworthy but not obligatory." The point to note here is that the four "regulative principles" (as the community's disavowals are called) constitute in this, and its affiliated communities, as basic morality, even if many would consider them supramoral ideals (Perrett 1998, pp. 31-42).
} 
the yoga paradigm, and the bhakti paradigm. The dharma and bhakti paradigms form a value polarity, with yoga as the linking element between the two. Dharma as normativity emphasizes values of duty, honoring obligation, and observance of regulation, thus locating it largely in deontic and consequentialist normative ethics that is sensitive to the recognition of rights and the observance of duties. Normative dharma includes a sense of duty with respect to all living beings, all of whom have rights by virtue of their non-material identities being qualitatively equal to all other beings, possessing sentience and the potential to realize personhood.

On the opposite end of this value polarity is the bhakti paradigm, which emphasizes contextualized responsiveness and responsibility to individual beings, rooted in reverence that acknowledges a divine reality as the source of all life and that therefore makes all life sacred. I suggest that, while cultivated within a moral space circumscribed by dharma (both descriptive and normative), bhakti particularly resonates with the ethics of care approach to human-nonhuman animal relations. Further, because bhakti that is directed to the divinity Krishna is especially concerned with the care of bovines (go-seva), this particular inflection of the bhakti paradigm is an especially important locus for comprehending Hindu animal ethics both as ideal and as an often-challenging practice.

We also briefly considered abolitionist objections to animal—particularly bovine-care as practiced in Hindu traditions. These objections give important cause to reassess current practices and to do all that is possible to eliminate abuse. However, with few exceptions, Hindus will not accept the idea that humans should have no involvement with bovines whatsoever. Rather, they regard human-bovine engagement as a major example of how human-nonhuman animal symbiosis functions in the greater context of a world order of interdependence. Such engagement, if practiced conscientiously (according to principles of dharma, yoga, and bhakti), offers a viable, potentially transformative alternative to the essentially parasitic way of life based on an extractive economy that human society has come to regard as the norm (Ranganathan 2017b, pp. 177-178).

Together, value orientations of dharma and bhakti, linked with practices of yoga, may offer a comprehensive basis for recognizing certain nonhuman animals as citizens-in at least an analogical sense-within communities that are committed to these values. These values are rooted 
in the vision that all creatures, being of divine origin, have their own trajectories of spiritual progress that may involve enriching interaction with humans. Further, such interactions can occur by conscious cultivation of habits that are liberative for both humans and nonhumans. Through such devotional practice, full personhood in relationship with the primordial supreme person can be realized. Finally, commitment to these values comes with recognition that they afford self-transformation as well as world-transformation, leading toward the full affirmation and protection of all sentient beings' value and dignity.

\section{References}

Alexander, Larry, and Michael Moore. 2016. Deontological Ethics. In The Stanford Encyclopedia of Philosophy, ed. Edward N. Zalta. https://plato.stanford. edu/archives/win2016/entries/ethics-deontological/. Accessed 26 December 2018.

Babaji, Ananta Das, and Advaita dāsa (trans.). 2010. Śrī-Śrī Prema Bhakti Candrikā [of] Śrīla Narottama Dāsa Thākura Mahāsaya. Mathura: Sri Krishna Chaitanya Shastra Mandir.

Bryant, Edwin F. 2009. The Yoga Sütras of Patañjali. New York: North Point Press. Bryant, Edwin F. 2017. Bhakti Yoga: Tales and Teachings from the Bhägavata Purāna. New York: North Point Press.

Clark, Stephen R.L. 2011. Animals in Classical and Late Antique Philosophy. In The Oxford Handbook of Animal Ethics, ed. Tom L. Beauchamp and R.G. Frey, 35-60. Oxford: Oxford University Press.

Cochrane, Alasdair. 2010. An Introduction to Animals and Political Theory. London: Palgrave Macmillan.

Cochrane, Alasdair. 2012. Animal Rights Without Liberation: Applied Ethics and Human Obligations. New York: Columbia University Press.

Dalmiya, Vrinda. 2016. Caring to Know: Comparative Care Ethics, Feminist Epistemology, and the Mahābhārata. Delhi: Oxford University Press.

Davis, Donald R., Jr. 2010. The Spirit of Hindu Law. Cambridge: Cambridge University Press.

Debroy, Bibek (trans.). 2015. The Mahabharata, 10 vols. Gurgaon: Penguin.

Donaldson, Sue, and Will Kymlicka. 2013. Zoopolis: A Political Theory of Animal Rights. Oxford: Oxford University Press. 
Donovan, Josephine, and Carol J. Adams (eds.). 2007. The Feminist Care Tradition in Animal Ethics: A Reader. New York: Columbia University Press.

Ellis, Thomas B. 2013. On the Death of the Pilgrim: The Postcolonial Hermeneutics of Jarava Lal Mehta. Dordrecht: Springer.

Fink, Charles K. 2013. The Cultivation of Virtue in Buddhist Ethics. Journal of Buddhist Ethics 20. http://blogs.dickenson.edu/buddhistethics/. Accessed 18 October 2018.

Francione, Gary L. 2004. Animals: Property or Persons? In Animal Rights: Current Debates and New Directions, ed. Cass R. Sunstein and Marth C. Nussbaum, 108-144. Oxford: Oxford University Press. Available at http://law.bepress. com/rutgersnewarklwps/art21.

Frazier, Jessica. 2017. Hindu Worldviews: Theories of Self, Ritual and Reality. London: Bloomsbury.

Freeman, Carrie Packwood. 2010. Embracing Humanimality: Deconstructing the Human/Animal Dichotomy. In Arguments About Animal Ethics, ed. Greg Goodale and Jason Edward Black. Lanham, MD: Lexington Books.

Ganguli, Kisari Mohan (trans.). 1991 [1970]. The Mahabharata of KrishnaDwaipayana Vyasa. New Delhi: Motilal Banarsidass.

Glucklich, Arial. 1994. The Sense of Adharma. New York: Oxford University Press.

Goswami, H.D. 2015. A Comprehensive Guide to Bhagavad-Gītā with Literal Translation. Gainesville, FL.: Krishna West.

Govindrajan, Radhika. 2018. Animal Intimacies: Interspecies Relatedness in India's Central Himalayas. Chicago: University of Chicago Press.

Haberman, David L. 2006. River of Love in an Age of Pollution: The Yamuna River of North India. Berkeley: University of California Press.

Holdrege, Barbara A. 2013. Vraja-Dhāman: Krishna Embodied in Geographic Place and Transcendent Space. In The Bhāgavata Purāna: Sacred Text and Living Tradition, ed. Ravi M. Gupta and Kenneth R. Valpey, 91-116. New York: Columbia University Press.

Howard, Veena Rani. 2018. Lessons from 'The Hawk and the Dove': Reflections on the Mahābhārata's Animal Parables and Ethical Predicaments. Sophia 57: 119-131.

Kansal, Vishrut. 2016. The Curious Case of Nagaraja in India: Are Animals Still Regarded as 'Property' With No Claim Rights? Journal of International Wildlife Law and Policy 19 (3): 256-267. https://doi.org/10.1080/13880292. 2016.1204885. 
Korsgaard, Christine M. 2011. Interacting with Animals: A Kantian Account. In The Oxford Handbook of Animal Ethics, ed. Tom L. Beauchamp and R.G. Frey, 91-118. Oxford: Oxford University Press.

Long, Jeffery D. 2013. The Dharma Paradigm and Ethos: Some Insights from Jainism and Vedānta. International Journal of Dharma Studies 1: 2. https:// doi.org/10.1186/2196-8802-1-2.

Monier-Williams, Monier. [1899] 1995. Dharma. In A Sanskrit-English Dictionary. Delhi: Motilal Banarsidass.

Neiman, Susan. 2008. Moral Clarity: A Guide for Grown-Up Idealists. Orlando: Harcourt.

Nussbaum, Martha. 2011. The Capabilities Approach and Animal Entitlements. In The Oxford Handbook of Animal Ethics, ed. Beauchamp and Frey. Oxford: Oxford University Press.

Perrett, Roy W. 1998. Hindu Ethics: A Philosophical Study. Honolulu: University of Hawai'i Press.

Prentiss, Karen Pechilis. 1999. The Embodiment of Bhakti. New York: Oxford University Press.

Ranganathan, Shyam (ed.). 2017a. The Bloomsbury Research Handbook of Indian Ethics. London: Bloomsbury.

Ranganathan, Shyam. 2017b. Patañjali’s Yoga: Universal Ethics as the Formal Cause of Autonomy. In The Bloomsbury Research Handbook of Indian Ethics, ed. Shyam Ranganathan, 177-202. London: Bloomsbury.

Rasmussen, Larry L. 2013. Earth-Honoring Faith: Religious Ethics in a New Key. Oxford: Oxford University Press.

Schuster, Joshua. 2016. The Vegan and the Sovereign. In Critical Perspectives on Veganism, ed. Jodey Castricano and Rasmus R. Simonsen, 203-223. London: Palgrave Macmillan.

Schweig, Graham M. 2013. The Rāsa Lìlā of Krishna and the Gopīs: On the Bhāgavata's Vision of Boundless Love. In The Bhägavata Purāna: Sacred Text and Living Tradition, ed. Ravi M. Gupta and Kenneth R. Valpey, 117-141. New York: Columbia University Press.

Sinha, Jadunath. 1983. Jivagosvamis Religion of Devotion and Love. Varanasi: Chowkhamba Vidyabhavan.

Stamm, Katrin. 2015. On the Moral and Spiritual Implications of the Fivefold Sacrifice: Metaphysical Obligations to the Divine in Nature According to Vaishnava Texts and in Contrast with Immanuel Kant. Journal of Vaishnava Studies 24 (1) (Fall): 91-120.

Steiner, Gary. 2013. Animals and the Limits of Postmodernism. New York: Columbia University Press. 
Stewart, James. 2017. Dharma Dogs: Can Animals Understand the Dharma? Textual and Ethnographic Considerations. Journal of Buddhist Ethics, vol. 24. Retrieved on January 10, 2019 from http://blogs.dickinson.edu/ buddhistethics/?s=dharma+dogs.

Sukthankar, Vishnu S. (ed.). 1942. The Mahäbhārata, Critical ed. Poona: Bhandarkar Oriental Research Institute.

Sutton, Nicholas. 2000. Religious Doctrines in the Mahäbhärata. Delhi: Motilal Banarsidass.

Swāmī, Bhānu (trans.). 2006. İ́sopanisad Commentary by Madhvācārya, Vedānta Deśika, Baladeva Vidyābhūsaṇa, Bhaktivinoda Thākura. Chennai: Sri Vaikuntha Enterprises.

Törzsök, Judit. 2007. Friendly Advice by Narayana \& King Vikrama's Adventures. The Clay Sanskrit Library. New York: New York University Press.

Whicher, Ian. 1998. The Integrity of the Yoga Darsana: A Reconsideration of Classical Yoga. Albany, NY: State University of New York Press.

Wise, Steven M. 2011. Animal Rights, One Step at a Time. In Animal Rights: Current Debates and New Directions, ed. Cass R. Sunstein and Marth C. Nussbaum, 16-50. Oxford: Oxford University Press.

Young, Rosamund. 2003. The Secret Life of Cows: Animal Sentience at Work. Preston: Farming Books.

Zagzebski, Linda Trinkaus. 2004. Divine Motivation Theory. Cambridge: Cambridge University Press.

Open Access This chapter is licensed under the terms of the Creative Commons Attribution 4.0 International License (http://creativecommons.org/licenses/by/ $4.0 /$ ), which permits use, sharing, adaptation, distribution and reproduction in any medium or format, as long as you give appropriate credit to the original author(s) and the source, provide a link to the Creative Commons license and indicate if changes were made.

The images or other third party material in this chapter are included in the chapter's Creative Commons license, unless indicated otherwise in a credit line to the material. If material is not included in the chapter's Creative Commons license and your intended use is not permitted by statutory regulation or exceeds the permitted use, you will need to obtain permission directly from the copyright holder.

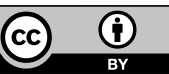

